\title{
Sikap Toleransi dan Tipe Kepribadian Big Five pada Mahasiswa UIN Sunan Gunung Djati Bandung
}

\author{
Asti Meiza \\ UIN Sunan Gunung Djati, Jl.A.H.Nasution No.105 Bandung \\ e-mail : asti.meiza@uinsgd.ac.id
}

\begin{abstract}
Indonesia is a big country with high pluralism. Country like Indonesia requires a high tolerance attitude. This research aimed to obtain the description about tolerance in the students based on personality type. The participants were 350 UIN Sunan Gunung Djati Bandung's students with quantitative approach. The variables were personality type and tolerance attitude. Personality types using a scale compiled from the Big Five theory formulated from the International Personality Item Pool (IPIP). Tolerance attitude was measured using the scale developed by van der Waltz. The results show that the type of personality Conscientious dominates the subject and there is no subject that has the Agreeableness type. From the four personality types, Analysis of Variance (Anova) found no significant difference in their tolerance attitudes. It seems that the majority of UIN Sunan Gunung Djati's students have good moral values so they can tolerate the difference.
\end{abstract}

Keywords: big five factor, personality, student, moral value, tolerance

\begin{abstract}
Abstrak
Indonesia adalah negara besar yang memiliki berbagai kemajemukan. Negara seperti Indonesia memerlukan sikap toleransi yang tinggi. Penelitian ini ingin memperoleh gambaran sikap toleransi pada mahasiswa berdasarkan tipe kepribadian. Penelitian mengambil subjek 350 mahasiswa UIN Sunan Gunung Djati Bandung dengan pendekatan kuantitatif. Variabel yang dilibatkan adalah tipe kepribadian dan sikap toleransi. Tipe kepribadian menggunakan skala yang disusun dari teori Big Five yang dirumuskan dari International Personality Item Pool (IPIP). Untuk sikap toleransi diukur dengan menggunakan skala yang dikembangkan oleh van der Waltz. Hasil yang diperoleh adalah tipe kepribadian Conscientious mendominasi subjek dan tidak ada satu subjekpun yang memiliki tipe kepribadian Agreeableness. Sedangkan untuk keempat tipe kepribadian yang ada, Analisis Variansi (Anava) tidak ditemukan perbedaan yang signifikan pada sikap toleransi mereka. Diduga mayoritas mahasiswa UIN Sunan Gunung Djati memiliki nilai moral yang baik sehingga bisa toleran dalam menerima perbedaan.
\end{abstract}

Kata Kunci: big five factor, kepribadian, mahasiswa, nilai moral, toleransi

\section{Pendahuluan}

Indonesia adalah negara besar yang terdiri dari 1340 suku bangsa yang masingmasing memiliki budaya (Na'im \& Syaputra, 2010). Selain suku bangsa, kemajemukan Indonesia juga ada pada agama. Terdapat enam agama yang diakui di Indonesia yaitu Islam, Kristen Protestan, Katolik, Hindu, Buddha, dan Kong $\mathrm{Hu} \mathrm{Cu}$, seperti yang tersaji pada Tabel 1. Namun kemajemukan di Indonesia ibarat pisau bermata dua. Di satu sisi kekayaan budaya bisa menjadi modal untuk berbagai hal karena bisa menjadi sumber inspirasi bagi berbagai sendi kehidupan bernegara. Di sisi lain berpotensi menjadi sumber konflik. Apalagi jika kesadaran masyarakat akan toleransi masih rendah.

Tabel 1

Komposisi Agama di Indonesia

\begin{tabular}{lcc}
\hline Agama & $\%$ & Jumlah absolut (juta) \\
\hline Islam & 87.2 & 207.2 \\
Kristen & 6.9 & 16.5 \\
Katolik & 2.9 & 6.9 \\
Hindu & 1.7 & 4.0 \\
Buddha & .7 & 1.7 \\
Konghucu & .05 & .1 \\
\hline Catatan. Dari "Kewarganegaraan, Suku Bangsa, \\
Agama, dan
\end{tabular}


Indonesia," oleh A. Na'im dan H. Syaputra, 2010, Jakarta: Badan Pusat Statistik.

Satu tahun terakhir, Bhinneka Tunggal Ika diuji oleh berbagai konflik yang memecah belah. Rasa fanatik dan diskriminatif terhadap etnis tertentu mengemuka. Latar belakang politik menjadi sumber perpecahan di kalangan masyarakat, terutama di kota-kota besar di pulau Jawa yang lebih dominan multi etnisnya. Paham Primordialisme dan Etnosentrisme yang sangat kuat muncul di tengah masyarakat sehingga dikhawatirkan Indonesia akan menjadi negara yang rawan konflik horizontal.

Dari tahun ke tahun jumlah kasus intoleransi meningkat (Komnas HAM, 2017). Tahun 2014 tercatat 74 kasus intoleransi. Tahun 2015 menjadi 87 kasus dan tahun 2016 hampir 100 kasus. Bentukbentuk intoleransi itu antara lain melarang aktivitas keagamaan tertentu, merusak rumah ibadah, diskriminasi terhadap penganut agama tertentu, intimidasi, dan pemaksaan keyakinan. Dalam sebuah diskusi dalam rangka HUT ke 53 Ikatan Mahasiswa Muhammadiyah (IMM) pada bulan Maret 2017 di Jakarta, muncul pernyataan bahwa Indonesia mengalami darurat intoleran terkait dengan semakin banyaknya kegiatan-kegiatan intoleran yang terjadi secara nasional (Yulianto, 2017). Dalam posisi ini mahasiswa berada di pihak yang tidak mendukung kepada intoleran. Namun bagaimana dalam posisi sebaliknya?

Seperti yang dimuat dalam website https://www.cnnindonesia.com terkait insiden intoleran di asrama mahasiswa asal Papua di Yogyakarta pada Juli 2016 (Kusumadewi, 2016). Kejadian ini menempatkan Yogyakarta menjadi kota yang makin tidak toleran. Tahun 2014 The Wahid Institute (sekarang Wahid Foundation) menobatkan Yogyakarta sebagai kota paling tidak toleran nomor dua seIndonesia karena dari total 154 kasus intoleransi, 21 di antaranya terjadi di
Yogyakarta. Tahun berikutnya 2015, Wahid Foundation mencatat dari 190 kasus intoleransi, 10 di antaranya terjadi di Yogyakarta. Ini menempatkan Yogyakarta sebagai kota intoleran keempat.

Sementara pada tanggal 17 Mei 2017 sebuah acara diskusi buku tentang Pendidikan Islam di UIN Sultan Syarif Kasim Riau dibubarkan oleh kelompok mahasiswa intoleran yang menolak budaya dialog di ruang akademik. Disinyalir Badan Eksekutif Mahasiswa (BEM) berada di balik kegiatan intoleran ini. Intoleran sendiri berarti tidak toleran; tidak tenggang rasa (Kamus Besar Bahasa Indonesia, 2016).

Beberapa istilah yang lekat dalam konteks ini yaitu radikalisme, intoleransi, dan terorisme. Ketiga kata ini seolah seperti tiga serangkai. Berikut definisi masingmasing kata. Menurut Kamus Besar Bahasa Indonesia, radikalisme adalah paham atau aliran yang radikal dalam politik; paham atau aliran yang menginginkan perubahan atau pembaha-ruan sosial dan politik dengan cara kekerasan atau drastis; sikap ekstrem dalam aliran politik. Sedangkan terorisme adalah orang yang menggunakan kekerasan untuk menimbulkan rasa takut, biasanya untuk tujuan politik. Kepala Divisi Humas Polri Irjen Pol Setyo Wasisto dalam diskusi Membedah Revisi UndangUndang Anti Terorisme di Jakarta pada bulan Juni 2017 mengatakan bahwa: "intoleransi bertemu dengan radikalisme akan melahirkan terorisme" (Dewi, 2017). Sedangkan beberapa petinggi lainnya meminta masyarakat untuk waspada karena gerakan terorisme yang makin diminati oleh usia muda, kaum intelek dan bahkan juga kaum birokrat.

Munculnya berbagai tindakan intoleran dalam kehidupan bermasyarakat seperti menghina dan menjelek-jelekkan suku bangsa atau penganut agama lain, jelas bukan merupakan ajaran agama tertentu maupun norma budaya dari suku bangsa tertentu.

Munculnya intoleransi berasal dari kekeliruan memahami ajaran agama atau 
sempitnya cara pandang dan cara berpikir. Selain itu, intoleransi dapat juga timbul karena faktor-faktor lain yaitu sosial, budaya, politik, dan ekonomi (BLDKA, 2010). Lebih jauh ditemukan bahwa konflik-konflik sosial dalam wujud intoleransi hanya melekatkan agama sebagai faktor eksternal. Beberapa faktor yang diduga memengaruhi sikap intoleran dalam masyarakat, termasuk di kalangan mahasiswa, salah satunya yaitu kepribadian. Faktor kepribadian ini meliputi aspek genetis, jenis kelamin, usia dan kematangan emosi, pola asuh dan pola didik dalam keluarga, serta beberapa hal lain. Studi tentang kepribadian dan budaya memperlihatkan hubungan antara perkembangan individu dengan setting sosiokultural (Pervin \& John, 2004). Karena itu dalam penelitian ini akan diteliti tentang sikap toleran pada mahasiswa dikaitkan dengan tipe kepribadian. Penelitian sejenis pernah dilakukan oleh Badan Litbang dan Diklat Kementerian Agama RI di tujuh perguruan tinggi umum . Namun penelitian ini dilakukan di lingkungan perguruan tinggi Islam dengan harapan mahasiswa yang menjadi subjek penelitian memiliki nilai moral yang lebih baik daripada yang tidak mendalami agama.

Toleransi umat Islam sudah dimulai sejak zaman Rasulullah Saw. Dalam Sirah Nabawiyyah bisa diketahui sikap Rasulullah terhadap pemeluk agama lain, kaum Kristen, Yahudi, bahkan kaum musyrikin sekalipun (al-Mubarakfuriyy, 2008). Perjuangan Rasulullah bahkan didukung oleh pamannya Abu Thalib. Rasulullah sangat memelihara harmoni sehingga kaum non muslim hidup dengan tenang. Penelitian sejenis pernah dilakukan oleh Bukhori (2012) yang melihat pengaruh fundamentalisme agama dan kontrol diri pada toleransi terhadap umat Kristiani pada jamaah majlis taklim di Semarang. Diperoleh hasil bahwa semakin tinggi fundamentalisme agama maka semakin rendah toleransi terhadap umat Kristiani dan semakin tinggi kontrol diri maka semakin tinggi toleransi terhadap umat Kristiani.

\section{Teori Kepribadian}

Menurut Kamus Besar Bahasa Indonesia, kepribadian diartikan sebagai sifat hakiki yang tercermin pada sikap seseorang atau suatu bangsa yang membedakan dari orang atau bangsa lain. Kepribadian adalah perangai atau perilaku yang muncul sebagai akibat interaksi dinamis antara karakteristik fisik dan mental pada diri individu yang berkembang sesuai dengan pendidikan dan lingkungan sosialnya.

Dalam Pervin dan John (2004) disebutkan perkembangan teori kepribadian dari masa ke masa. Dimulai dari Sigmund Freud (1856-1939) dengan Teori Psikodinamis yang menghasilkan Teori Psikoanalitis Kepribadian ala Freud. Selanjutnya ada Carl R. Rogers (1902-1987) dengan Teori Fenomenologis mengembangkan Teori Kepribadian PersonCentered. Sementara pendekatan untuk sifat-sifat terhadap kepribadian dilakukan oleh Allport, Eysenck, dan Cattell. Allport (dalam Hall \& Lindzey, 2005) mendefinisikan kepribadian sebagai organisme psikofisiologis yang dapat digunakan individu untuk menyesuaikan diri dengan lingkungan fisik dan lingkungan sosial. Organisme psikis meliputi bakat, minat, sikap, kecerdasan, emosi, kemampuan berpikir, berimajinasi, dan memori, sedangkan organisme fisik berhubungan dengan kondisi fisik, seperti tinggi badan, berat badan, dan kurus gemuk (Dariyo, 2003).

Pendekatan lain mengelompokkan teori kepribadian utama menjadi empat macam. Pertama, Psychodynamic Theory yang diperkenalkan oleh Sigmund Freud, yang membagi tiga hal pembentuk sistem dalam diri manusia yaitu id, superego, dan ego. Berikutnya adalah Neo-Freudian Personality Theory yang diteliti oleh Karen Horney yang membagi kepribadian menjadi tiga bagian yaitu Compliant Individual, Aggressives Individual, dan Detached 
Individual. Ketiga adalah Trait Theory yang diteliti oleh Costa dan McCrae pada rentang waktu 1990, 1994, dan tahun 2003 yang mengelompokkan manusia menjadi lima karakter yaitu Extraversion, Neurotism, Agreeableness, Conscienti-ousness, dan Openness to Experience, yang lalu berkembang menjadi Teori Model Kepribadian Big Five. Keempat adalah Carl Jung Theory yang mengklasifikasikan individu menjadi Extrovert dan Introvert.

Dalam penelitian ini digunakan variabel kepribadian yang diukur dengan Big Five Personality yang dikembangkan dari Trait Theory. Westen dan Shedle (2007) mendefinisikan trait sebagai kecenderungan emosional, kognitif, dan tingkah laku yang merupakan dimensi kepribadian mendasar, yang membedakan satu individu dengan individu lainnya. Teori Trait diturunkan dari kata-kata yang sering digunakan individu untuk mengelompokkan diri mereka dan orang lain dalam kehidupan sehari-hari yang terkait dengan kata-kata sifat (Sari, 2010). Sejak tahun 1980-an banyak peneliti menyepakati bahwa perbedaan individu dapat dikelompokkan menjadi lima dimensi yang luas, di antaranya John \& Srivastava tahun 1999 dan McCrae \& Costa tahun 2003. Ini yang kemudian dikenal dengan dimensi Big Five.

\section{Model Kepribadian Big Five}

Awalnya Model Kepribadian Big Five dikembangkan oleh Norman pada tahun 1963 dengan menggunakan hasil penelitian Allport dan Cattell serta beberapa penelitian lainnya. Lalu pada tahun 1981, Goldberg melakukan hal serupa dan memantapkan bahwa faktor Big Five menjadi faktor eksistensi. Seperti telah disebutkan di atas, kelima faktor ini adalah Openness (O), Conscientiousness (C), Extraversion (E), Agreeableness (A), dan Neuroticism (N). Oleh John (1990) ini disingkat menjadi OCEAN. Pada Tabel 2 dirinci faktor Big Five dengan karakteristik yang muncul sesuai skor (Pervin \& John, 2004). Sifat-sifat ini terus diuji seiring berkembangnya waktu pada kelompok populasi yang beragam dan ditemukan bahwa sifat-sifat tersebut ternyata memang muncul pada banyak budaya dan kelompok bahasa.

Penelitian lain menyebutkan bahwa sifat-sifat ini sudah berkembang dari masa kanak-kanak dan di masa remaja. Sudah diteliti bahwa terdapat hubungan antara temperamen bayi, kepribadian masa kanakkanak dengan kepribadian Big Five di masa dewasa (Pervin \& John, 2004). Dengan alasan ini maka pengambilan mahasiswa sebagai subjek penelitian adalah make

Tabel 2

Indikator Big Five Personality

\begin{tabular}{lc}
\hline Tipe kepribadian & Indikator \\
\hline Extraversion (E) & Extravert, banyak bicara, tegas, verbal, energik, berani, aktif, nekat,
\end{tabular}
giat, tidak sabar

Agreeableness (A)

Baik hati, suka bekerja sama, kooperatif, simpatik, ramah, dapat dipercaya, penuh pertimbangan, menyenangkan, bersedia menyetujui, suka menolong, murah hati

Conscientiousness (C)

Teratur, sistematis, teliti, rapi, efisien, hati-hati, mantap, sungguhsungguh, tepat waktu

Emotional Stability (ES)

Tidak cemburu, tidak emosional, santai, tenang sekali, tidak dapat dirangsang, tidak merasa diperlukan

Intellect/Openness to Experience (I) Pandai, kreatif, rumit, imajinatif, cerdas, filosofis, artistik, mendalam, inovatif, mawas diri

Catatan. Adaptasi dari "Uji Validitas Alat Ukur Big Five Personality Personality (Adaptasi dari IPIP) Pada

Mahasiswa Universitas Islam Negeri Syarif Hidayatullah Jakarta, oleh D.A. Sari, 2010, h. 17. 
sense. Dalam rancangan alat ukur kepribadian Big Five Personality tipe Neuroticism (N) diberi nama lain yaitu Emotional Stability (ES).

\section{Toleransi}

Dari segi bahasa, toleransi adalah sikap saling menghormati dan menghargai antar kelompok atau antar individu dalam masyarakat atau dalam lingkup lainnya. Menurut Kamus Merriam-Webster, toleransi adalah sikap yang berkaitan dengan, atau respon terhadap karakteristik individu atau kelompok. Toleransi agama khususnya dilihat sebagai sikap bahwa toleransi yang mengalir dari motif religius diarahkan pada orang atau kelompok agama lain. Karena itu istilah 'toleransi' dipakai pada banyak bidang, di antaranya dalam kehidupan beragama.

Definisi toleransi beragama (religious tolerance) tidak mudah ditemukan secara eksplisit. Sebagian besar studi tentang toleransi beragama lebih banyak mendeskripsikan sikap yang disebut toleran. Power (2002, dalam Hermawati, Paskarina, \& Runiawati, 2016) menyatakan bahwa toleransi adalah pengecualian (exception) atas hal-hal yang sebenarnya tidak disukai, tapi tetap dibiarkan dilakukan.

Toleransi beragama merupakan sikap saling menghormati dan menghargai penganut agama lain. Sikap toleransi beragama di antaranya tidak memaksa orang lain untuk menganut agama yang kita anut; tidak melarang penganut agama lain untuk beribadah sesuai dengan keyakinan dan ajaran agama mereka; tidak menghina ajaran agama lain. Dalam penelitian ini diambil kasus khusus yaitu menelusuri lebih jauh tentang sikap toleransi mahasiswa UIN terhadap pemeluk Syiah.

Menurut Gray (2003) sesungguhnya kemanusiaan itu tidaklah ada. Yang ada hanyalah manusia yang didorong oleh keinginan untuk berkonflik dan tunduk terhadap segala bentuk kelemahan dan penghakiman. Karenanya manusia sebagai makhluk sosial tidak akan benar-benar mampu hidup bersama dalam kedamaian. Perselisihan akan terus terjadi baik antar individu, kelompok maupun bangsa disebabkan perbedaan minat, aspirasi, ras, agama, dan kepercayaan. Menurut Alford (2009) agama dan kepercayaan dalam bentuk fundamentalis agama merupakan penyebab banyak konflik di dunia, termasuk intoleransi beragama.

Dalam menyikapi perbedaan, ada beberapa kategori individu menurut Bennett (1993, dalam Broer, de Muynck, Potgieter, Wolhuter, \& van der Walt, 2014). Kategori pertama adalah denial of difference (menolak perbedaan). Individu dalam kategori ini tidak dapat menafsirkan perbedaan agama. Sikapnya stereotip terkadang disertai perilaku menyimpang dari ajaran agama. Ada kecenderungan untuk mengusir orang asing secara tidak manusiawi yang mengisolasi mereka dalam kelompok homogen.

Kategori kedua, defence against difference (bertahan melawan perbedaan). Seseorang dalam kategori ini mengenal perbedaan agama ditambah dengan evaluasi negatif terhadap variasi agama. Pemikirannya dicirikan oleh dikotomis 'kita-mereka' dan sering disertai stereotip negatif. Individu yang masuk kategori ini memiliki kecenderungan untuk ber- dakwah terhadap agama lain. Setiap pernyataan netral atau positif tentang agama lain dapat ditafsirkan sebagai serangan terhadap agamanya sendiri.

Ketiga, minimization of difference (meminimalisasi perbedaan). Seseorang dalam kategori ini mengenali dan menerima perbedaan agama secara dangkal seperti ritual dan kebiasaan sehari-hari. Ada kecenderungan untuk mendefinisikan dasar kesamaan dalam istilah egosentris (berdasarkan apa yang disukai). Mengerti bahwa ada kesamaan pada manusia sebagai makhluk supernatural atau makhluk sosial. Mencoba memasukkan perbedaan ke dalam hal-hal yang sudah familiar.

Keempat, acceptance of difference (menerima perbedaan). Seseorang dalam 
kategori ini mengenali dan menghargai perbedaan agama dalam perilaku dan nilai. Perbedaan agama dianggap sebagai solusi alternatif yang layak diorganisir. Kategori perbedaan secara sadar dijabarkan. Dia dapat menganalisis interaksi kompleks dalam perbedaan agama

Kelima, adaptation to difference (beradaptasi dengan perbedaan). Orang dalam kategori ini mampu mengembangkan kemampuan berkomunikasi antar agama dan memanfaatkan empati atau pengalihan referensi. Orang ini mampu secara sadar mengubah perspektif menjadi elemen cara alternatif memandang dunia keagamaan dan bertindak secara religius dengan cara yang sesuai di wilayah tersebut. Dia juga bisa mengubah tingkah laku sepenuhnya menjadi bingkai religius yang berbeda tanpa banyak friksi. Pengetahuan dan perilaku terkait perbedaan antara agamaagama menjadi lebih fleksibel dan mudah berubah.

Keenam, integration of difference (menyatu dalam perbedaan). Seseorang dalam kategori ini mampu menginternali-sasi kerangka acuan bi-religius atau multireligius. Dia mampu mempertahankan definisi identitas yang "marjinal" terhadap agama tertentu, dan melihat diri sebagai "dalam proses." Dia dapat menggunakan kerangka acuan beberapa agama dalam mengevaluasi fenomena, dan mampu menerima sebuah identitas yang tidak didasarkan pada agamanya. Dia dapat memfasilitasi kontak konstruktif antara agama untuk diri sendiri dan orang lain, dan bersedia berpartisipasi sampai batas tertentu dalam "kelompok referensi marjinal."

Konteks intoleransi beragama seperti sesuatu yang bertentangan dengan ajaran agama. Semua agama mengajarkan cinta kasih terhadap sesama manusia bahkan kepada semua makhluk ciptaan Tuhan. Namun yang terjadi justru munculnya ketegangan dan sikap serta perilaku yang bertentangan dengan ajaran agama dimana pada saat pemeluk suatu agama merasa pemeluk agama lainnya sebagai ancaman. Ada semacam kecenderungan jika seseorang mendalami agamanya maka yang terjadi justru munculnya fanatisme dan berujung menganggap dirinya paling benar dan agama serta keyakinan kelompok di luarnya sebagai sesuatu yang keliru. Dengan berbekal bahwa agamanya adalah yang paling benar, tidak sedikit yang lalu memaksakan aturan-aturan dalam tatanan kehidupan bermasyarakat untuk diatur sesuai ajaran agamanya saja.

Toleransi merupakan hal yang mendasar untuk mengembangkan sikap saling menghormati, saling memahami, dan saling menghargai perbedaan agar tercipta suasana rukun antar umat beragama (Bahari, 2010). Dalam sudut pandang Psikologi, toleransi merupakan sebuah kontrol sosial dimana setiap individu diharapkan memahami tingkah laku atau keyakinan individu lain yang berbeda dari sisi agama ataupun suku dan budaya serta berusaha mengontrol respon negatif terhadap individu lain yang berbeda tersebut (Dijiker \& Koomen, 2007). Toleransi akan mengarahkan individu untuk membangun harmoni dalam kehidupan bermasyarakat dengan individu lain yang berbeda latar belakang sosial budaya.

Kebutuhan akan toleransi tidak hanya meningkat karena epidemi atau kejahatan melainkan karena interaksi sosial sehari-hari membutuhkannya untuk saling menghormati dan menjaga martabat. Badan Litbang dan Diklat Kementerian Agama RI melakukan penelitian di tujuh perguruan tinggi umum untuk mengetahui pengaruh kepribadian, keterlibatan organisasi, hasil belajar pendidikan agama, dan lingkungan pendidikan terhadap toleransi mahasiswa berbeda agama. Namun dalam penelitian ini dilakukan di lingkungan perguruan tinggi Islam dalam skala yang lebih sempit dengan hanya meneliti hubungan tipe kepribadian dengan sikap intoleransi pada mahasiswa perguruan tinggi agama, dalam hal ini, Islam. Karena di perguruan tinggi agama, di sini diambil 
agama Islam, hampir seratus persen mahasiswa adalah muslim. Menarik untuk diketahui apakah dengan iklim kampus yang homogen, rasa toleransi dan kasih sayang pada sesama akan lebih baik atau tidak. Diperkirakan mahasiswa yang menjadi subjek penelitian memiliki nilai moral yang lebih bijak daripada mahasiswa di perguruan tinggi yang heterogen. Nilai-nilai moral yang dibentuk oleh lingkungan dan agama sangat dipengaruhi oleh kepribadian.

\section{Moral}

Menurut Kamus Besar Bahasa Indonesia, moral adalah ajaran mengenai perbuatan, sikap, kewajiban, dan sebagainya; akhlak; budi pekerti; susila; kondisi mental yang membuat orang tetap berani, bersemangat, bergairah, berdisiplin, dan sebagainya; isi hati atau keadaan perasaan sebagaimana terungkap dalam perbuatan. Kata 'moral' berasal dari bahasa Latin moralis - mos, moris, yang berarti adat; istiadat; kebiasaan; cara; tingkah laku; kelakuan atau berasal dari kata mores yang berarti adat istiadat; kelakuan; tabiat; watak; akhlak; cara hidup. Moral terkait dengan aktivitas manusia yang bisa dipandang dari sisi baik/ buruk, benar/ salah dan tepat/ tidak tepat. Menurut Magnis-Suseno (dalam Nucci \& Narvaez, 2014) kata 'moral' selalu mengacu terhadap baik buruknya manusia. Pendidikan moral serta pembentukan karakter anakanak dan remaja tidak hanya hasil dari sekolah melainkan juga dibentuk lewat pengalaman pembelajaran informal melalui media dan model belajar lain di luar sekolah.

Menurut Lapsley (dalam Nucci \& Narvaez, 2014) identitas-diri moral dijadikan tujuan dari pendidikan. Dalam memberikan pendidikan kepada anak, mayoritas orang tua berambisi untuk menjadikan anak sebagai orang jenis tertentu yang memiliki sifat-sifat terpuji. Ini sejalan dengan tujuan negara dan lembaga pendidikan. Karenanya pembentukan moral anak dijadikan sebagai salah satu tujuan dasar pendidikan formal (Goodman \& Lesnick dalam Nucci \& Narvaez, 2014). Ajaran-ajaran Aristoteles dijadikan sebagai acuan pembentukan moral yang menyatakan bahwa pembentukan moral adalah masalah mengembangkan disposisi yang memungkinkan seseorang untuk menjalani kehidupan yang baik.

Dari sudut Psikologi, perkembangan karakter terkait dengan kognisi. Kualitas moral ditentukan oleh kedirian (selfhood) dan identitas. Gabungan keduanya dikenal juga dengan identitas-diri moral (moral self-identity). Menurut Lapsley (dalam Nucci \& Narvaez, 2014), pendekatan teoretis pada identitas-diri moral diikuti dengan implikasi pada pendidikan. Pada teori-teori identitas-diri, terdapat beragam sudut pandang ahli dalam menelitinya. Kant (1785-1988) menempatkan diri-moral di alam metafisika transendental yang aman dan jauh dari hal-hal yang merusak berupa nafsu dan keinginan. Karena jika bicara tentang moral, seringkali diasumsikan kehendak dikelilingi oleh kekuatan yang berlawanan yaitu kekuatan akal dan nafsu. Kesulitan para ahli merumuskan cara mempertahankan merupakan tradisi rasional moral sekaligus membangun psikologi moral. Sebagian orang memasukkan moralitas ke dalam kepribadian mereka. Ini melahirkan pernyataan bahwa "identitas moral merupakan perbedaan individu yang didasarkan pada kepribadian."

Power (2002, dalam Hermawati, Paskarina, \& Runiawati, 2016) melakukan pendekatan yang berbeda untuk identitas moral yaitu dengan memasukkan dimensi sosial yang menghasilkan 'komunitas moral' karena menurut Power suasana moral tidak dihasilkan oleh individu sendirian melainkan bersama orang lain dalam lingkup budaya. Dengan kata lain, identitas moral adalah masalah identifikasi kelompok. Menarik untuk mengkaji bagaimana identitas moral dalam komunitas pendidikan, dalam hal ini kampus. Menurut Power, Higgins, dan Kohlberg (1989) 
anggota komunitas di lembaga pendidikan akan terdorong untuk memiliki solidaritas dan identifikasi kelompok. Pratt dkk. (2009, dalam Nucci \& Narvaez, 2014) menyebutkan keterlibatan pemuda dalam kelompok mendorong perkembangan rasa identitas yang ditandai dengan meningkatnya nilai-nilai moral dan perilaku prososial. Hart (dalam Power dkk. 1989) mencatat ada lima faktor pembentuk identitas moral yaitu karakteristik watak yang melekat, karakteristik sosial (keluarga, budaya, kelas sosial), pertimbangan dan sikap moral, rasa diri, serta peluang untuk tindakan moral.

\section{Moral dan Kepribadian}

Selanjutnya akan dibicarakan tentang hubungan identitas moral dan kepribadian melalui beberapa penelitian. Penelitian Narvaez, Lapsley, Hagele, dan Lasky (2006) menunjukkan bahwa kesinambungan dan ketidaksinambungan moral direspon dengan cara yang berbeda. Walaupun di atas telah disinggung bahwa identitas moral menjadi target utama tujuan pendidikan akan tetapi ditemukan kesulitan untuk mengembangkannya ke dalam sistem pendidikan karena identitas moral sering dikonsepsikan sebagai perspektif orang dewasa. Tentu saja akan sulit menurunkannya ke dalam tahapan perkembangan. Akibatnya sulit pula menemukan strategi operasional dalam kurikulum di sekolah.

Karena analisis pada konsep identitasmoral belum membuatkan rumusan yang bisa dijadikan tujuan pendidikan maka sebagai alternatifnya, Kochanska, Gross, Lin, dan Nichols (2002) mengusulkan model tahapan munculnya moralitas. Pada fase pertama, keterikatan antara orang tua dan anak menjadi penting. Jika kualitas hubungan antara orang tua dan anak cukup baik maka pada diri anak terjadi pengadopsian nilai-nilai moral dari orang tua maupun pengasuh. Hasil penelitian Clark dan Ladd (2000, dalam Nucci \& Narvaez, 2014) menemukan bahwa melalui interaksi yang terhubung antara orang tua dan anak, anak mengembangkan orientasi sosio-emosi empatik yang berfungsi sebagai dasar untuk menafsirkan situasi sosial dan memberi tanggapan secara proporsional terhadap teman sebaya. Karena itu Kochanska, Koenig, Barry, Kim, dan Yoon (2010) menunjukkan bahwa dasar pengendalian diri, integritas serta keinginan moral sangat berhubungan.

Pada bagian sebelumnya telah disampaikan bahwa penelitian Hart (dalam Power dkk. 1989) juga menemukan pentingnya faktor komunitas sekolah dalam menumbuhkan identitas moral. Salah satu pendekatan kontemporer terhadap pendidikan moral yaitu mengambil perkembangan kognitif dari Piaget dan Durkheim. Menurut Piaget, lokus pembentukan moral ada di tangan individu dan teman sebayanya (Nucci \& Narvaez, 2014). Artinya anakanak secara aktif membangun cara berpikir tentang hal yang benar dan hal yang salah. Dalam konteks pendidikan karakter maka proses ini membutuhkan keteladanan dan penguatan untuk perilaku yang baik. Karenanya Durkheim menempatkan lokus pembentukan moral itu di tangan orang tua dan guru. Piaget dan Durkheim sepakat bahwa perilaku moral membutuhkan pemahaman kognitif dan kebebasan kehendak, bukan sekedar meniru. Bahkan menurut Durkheim, mengajarkan moralitas bukanlah berdakwah atau mengindoktrinasi.

\section{Islam Agama yang Sangat Toleran}

Menurut Kohlberg (1981) suasana moral sosial di sekolah harusnya menekankan rasa komunitas, nilai-nilai demokrasi, otonomi pribadi, hak dan kewajiban individu, arti permainan yang adil, dan tanggung jawab kolektif. Kohlberg menekankan pada perlunya ada teladan moral. Ini juga menjadi dasar pengambilan subjek penelitian di kampus dengan latar belakang agama karena sebagian mahasiswa berasal dari lembaga-lembaga pendidikan berbasis agama berupa pesantren ataupun madrasah. Di lembaga-lembaga ini ada sosok 'guru' atau 'ustadz' atau 'ajengan' yang dalam 
tradisi masyarakat Islam adalah tokoh panutan yang seluruh tindak tanduknya akan jadi teladan untuk umatnya. Termasuk dalam memperlakukan umat agama lain. Diyakini bahwa para ajengan merupakan representasi Nabi Muhammad dalam kehidupan kekinian yang akan mengimplementasikan ajaran-ajaran Islam yang bersumber dari Alquran dan hadis dalam kehidupan sehari-hari. Islam merupakan agama kasih sayang. Seperti yang tercantum dalam Alquran Surat Al-Anbiya ayat 107 yang artinya "Kami tidaklah mengutusmu (Muhammad) melainkan untuk (menjadi) rahmat (kasih sayang) bagi seluruh alam."

Dalam konteks teladan moral, maka mahasiswa yang sebelumnya mengenyam pendidikan di pesantren atau madrasah, diharapkan memiliki sikap toleransi yang bagus, terutama dalam menyikapi perbedaan-perbedaan di lingkungan kampus. Walaupun sama-sama beragama Islam, tidak bisa dihindarkan di kampus UIN terdapat berbagai aliran keyakinan. Contohnya terbelahnya Islam menjadi pengikut Ahlus Sunnah Wal Jamaah dan lainnya dimana termasuk di dalamnya Syiah, Ahmadiyyah dan sebagainya. Dalam kehidupan beragama di kampus, perbedaan aliran yang biasanya memberikan perbedaan pula dalam tatacara beribadah atau berpandangan, rawan menimbulkan friksi yang bisa memicu kepada intoleransi bahkan diskriminasi oleh kelompok mayoritas terhadap kelompok minoritas.

Dikenalkan juga istilah moral agama. Agama secara bahasa artinya 'tidak kacau.' Agama sering juga diartikan sebagai religiusitas. Sudah disinggung di atas bahwa sikap toleransi erat kaitannya dengan moral. Kondisi yang paradoks di Indonesia terjadi yaitu moral beragama naik tapi toleransi menurun atau intoleransi meningkat.

Walaupun setiap agama memiliki aspek universal, tapi ketika ikatan-ikatan keagamaan terbentuk, maka perasaan in group akan muncul dan menyebabkan setiap orang yang berada di luar ikatan tersebut dianggap sebagai out group dan diperlakukan berbeda, bahkan tidak jarang dicurigai akan menganggu ketahanan ikatan tersebut. Dalam konteks inilah, konflik dan perilaku kekerasan yang mengatasnamakan agama menjadi rentan muncul (Hermawati dkk., 2016).

Mahasiswa adalah salah satu elemen terpenting dalam masyarakat karena berada dalam fase memiliki idealisme untuk membuat segala sesuatu menjadi lebih baik dalam visi pribadinya. Ke depan diharapkan estafet kepemimpinan bangsa akan dilanjutkan oleh generasi muda yang sekarang menjadi mahasiswa walaupun dari segi fisik dan mental, mahasiswa berada dalam usia yang masih dalam pertumbuhan dimana mahasiswa berada di rentang usia 18-21 tahun. Hurlock (1968) menggolongkan mahasiswa ke dalam fase dewasa awal (early adulthood) yaitu dalam rentang usia 18 atau 20 tahun sampai 40 tahun. Dalam usia ini terjadi puncak pertumbuhan fisik dan digolongkan sebagai usia tersehat dari populasi manusia. Untuk segi psikologisnya, sebagian individu belum mencapai kematangan psikis yang mungkin disebabkan oleh ketidakmampuan orang tua dan keluarga untuk menyiapkan individu agar bisa menjalani tahapan kehidupannya dengan baik. Sedangkan dari segi tugas perkembangan pada fase ini meliputi memasuki dunia kerja lalu mengelola karier dengan baik, mencari pasangan lalu menikah, berperan dalam masyarakat, serta mengamalkan ajaran agama dengan baik.

Dari uraian di atas maka masalah dalam penelitian ini adalah menguji apakah terdapat perbedaan sikap toleransi dari subjek penelitian terkait dengan tipe kepribadian mereka. Hipotesis yang diajukan adalah $\mathrm{H}_{0}: \mu_{1}=\mu_{2}=\mu_{3}=\mu_{4}$ dan $\mathrm{H}_{1}$ : salah satu $\neq$, dimana $\mu$ adalah rata-rata skor karena pada Analisis Variansi yang merupakan teknik analisis data yang digunakan untuk meneliti perbedaan homogenitas dari dua kelompok data. Dari analisis ini bisa diketahui apakah terdapat 
perbedaan rata-rata skor beberapa kelompok yang diban-dingkan.

\section{Metode Penelitian}

Penelitian ini adalah penelitian kuantitatif dimana data-data hasil penelitian berupa angka atau numerik.

\section{Subjek Penelitian}

Subjek dalam penelitian ini adalah mahasiswa UIN Sunan Gunung Djati Bandung yang aktif kuliah berjumlah 19.889 orang. Peneliti menggunakan konsep Sugiyono (2015) dalam penentuan jumlah sampel dari populasi tertentu dengan taraf kesalahan 5\%, sehingga diperoleh jumlah sampel sebanyak 347 dan dibulatkan menjadi 350 subjek (Sugiyono, 2015, h. 131). Teknik sampling yang digunakan dalam penelitian ini adalah teknik random sampling. Dari pengukuran dan proses skoring untuk tipe kepribadian, data yang valid dan bisa dianalisis berjumlah 274 subjek.

\section{Instrumen Penelitian}

Penelitian ini memiliki dua variabel yaitu sikap toleransi berdasarkan tipe kepribadian. Sikap toleransi diukur dengan skala yang terdiri dari 39 item dan tipe kepribadian diukur dengan Skala Kepribadian Big Five yang merupakan adaptasi dari IPIP (International Personality Item Pool) yang terdiri dari 50 item. Berikut akan dijelaskan satu persatu mengenai alat ukur penelitian ini.

Skala toleransi. Skala toleransi disusun oleh van der Walt (2016) yang terdiri dari 42 item. Alat ukur ini dikembangkan berdasarkan beberapa kategori sikap religius dalam menyikapi perbedaan yang dikemukakan oleh Bennett (1993) yaitu: denial of difference (menolak perbedaan); defence against difference (bertahan melawan perbedaan); minimization of difference (meminimasi perbedaan); acceptance of difference (menerima perbedaan); adaptation to difference (beradaptasi dengan perbedaan); dan integration of difference (menyatu dalam perbedaan).

Kategori-kategori di atas diturunkan ke dalam item-item yang diberi skor sesuai skala Likert yaitu 1-5 dengan 1 menyatakan sikap 'Sangat Setuju' sampai 5 menyatakan 'Sangat Tidak Setuju.' Data diperoleh dalam skala ukur interval.

Karena alat ukur ini merupakan hasil adaptasi maka sebelum digunakan untuk pengambilan data, terlebih dahulu dilakukan proses uji coba (try out). Diperoleh koefisien reliabilitas yang dihitung dengan teknik Alpha Cronbach sebesar $\alpha=.795$. Ini memberikan informasi bahwa alat ukur ini cukup reliabel (handal).

Skala kepribadian big five. Skala Kepribadian Big Five merupakan adaptasi dari International Personality Item Pool (IPIP) yang dikembangkan pada EugeneSpringfield Community Sample (ESCS) periode 1990-an. Dalam rentang waktu satu periode tersebut, setiap tahun alat ukur ini diujicobakan dengan sejumlah item. Misal pada tahun 1994 diujikan 858 item, kemudian dilanjutkan dengan 285 item pada tahun 1995. Sedangkan Big Five Factor sendiri dikembangkan oleh Goldberg pada tahun 1992.

Indikator untuk Big Five Personality Scale yang diturunkan dari IPIP disajikan dalam tabel 2. Alat ukur ini terdiri dari 50 item dengan masing-masing 10 item untuk mengukur kelima tipe kepribadian. Setiap item diberi skor sesuai skala Likert yaitu 1 sampai 4. Diperoleh data berskala ukur interval. Pada tabel 3 disajikan interpretasi skor berdasarkan indikator.

Pada alat ukur Big Five Personality Scale ini tidak dilakukan proses ujicoba (try out) seperti halnya alat ukur toleransi. Pengambilan data dilakukan menggunakan alat ukur yang sudah diujicoba oleh Sari (2010) secara utuh untuk keseluruhan itemnya. 
Tabel 3

Skoring untuk Faktor Big Five

\begin{tabular}{|c|c|c|}
\hline Karakteristik untuk skor tinggi & Skala sifat & Karakteristik untuk skor rendah \\
\hline $\begin{array}{l}\text { Ingin tahu, minat yang luas, } \\
\text { kreatif, orisinal, imajinatif, tidak } \\
\text { tradisional }\end{array}$ & $\begin{array}{l}\text { Openness }(\mathrm{O}) \\
\text { Proaktif memberikan penghargaan } \\
\text { untuk diri sendiri serta toleran } \\
\text { untuk hal yang tidak biasa }\end{array}$ & $\begin{array}{l}\text { Konvensional, membumi, sedikit } \\
\text { minat, tidak artistik, tidak analitis }\end{array}$ \\
\hline $\begin{array}{l}\text { Terorganisir, dapat diandalkan, } \\
\text { pekerja keras, disiplin, tepat } \\
\text { waktu, cermat, rapi, ambisius, } \\
\text { keras hati }\end{array}$ & $\begin{array}{l}\text { Conscientiousness }(\mathrm{C}) \\
\text { Tekun dan motivasi dalam perilaku } \\
\text { yang mengarah pada tujuan }\end{array}$ & $\begin{array}{l}\text { Tidak berjuang, tidak dapat dian- } \\
\text { dalkan, malas, acuh, sembrono, } \\
\text { niat rendah, hedonistis }\end{array}$ \\
\hline $\begin{array}{l}\text { Dapat bersosialisasi, aktif, senang } \\
\text { bercakap-cakap, berorientasi pada } \\
\text { individu, optimis, menyukai } \\
\text { keceriaan, lembut }\end{array}$ & $\begin{array}{l}\text { Extraversion }(\mathrm{E}) \\
\text { Menilai kuantitas dan intensitas } \\
\text { interaksi }\end{array}$ & $\begin{array}{l}\text { Menahan diri, bijaksana, tidak } \\
\text { gembira, menyendiri, berorientasi } \\
\text { pada tugas, menarik diri, diam }\end{array}$ \\
\hline $\begin{array}{l}\text { Lembut, ramah, dipercaya, } \\
\text { membantu, memaafkan, mudah } \\
\text { dibujuk, terang-terangan }\end{array}$ & $\begin{array}{l}\text { Agreeableness }(\mathrm{A}) \\
\text { Menilai kualitas } \\
\text { interpersonal seseorang }\end{array}$ & $\begin{array}{l}\text { Klinis, kasar, curiga, tidak } \\
\text { kooperatif, pendendam, bengis, } \\
\text { pemarah, manipulatif }\end{array}$ \\
\hline $\begin{array}{l}\text { Cemas, gugup, emosional, tidak } \\
\text { aman, tidak cakap }\end{array}$ & $\begin{array}{l}\text { Neuroticism }(\mathrm{N}) \\
\text { Penilaian penyesuaian } \\
\text { ketidakstabilan emosi }\end{array}$ & $\begin{array}{l}\text { Tenang, rileks, tidak emosional, } \\
\text { kukuh, aman, puas diri }\end{array}$ \\
\hline
\end{tabular}

Teknik analisis data. Data dalam penelitian ini berskala ukur interval. Akan diolah dalam dua fase yaitu fase deskriptif dan fase inferensial. Langkah pertama adalah mengklasifikasikan subjek berdasarkan sikap toleransi ke dalam lima kategori. Selanjutnya skoring data hasil pengukuran untuk mengetahui tipe-tipe kepribadian subjek penelitian diolah sesuai dengan aturan skoring pada skala. Ini merupakan bagian dari statistika deskriptif. Selanjutnya adalah proses inferensial yaitu dilakukan pengujian hipotesis dengan analisis komparatif menggunakan uji statistik Analisis Variansi karena data berskala ukur interval. Pada tahapan ini dibandingkan apakah kelompok subjek penelitian yang terklasifikasi ke dalam tipetipe kepribadian memiliki sikap toleransi yang berbeda secara signifikan atau tidak.

\section{Hasil Penelitian dan Pembahasan}

\section{Statistika Deskriptif}

Gambaran toleransi mahasiswa UIN Sunan Gunung Djati Bandung tersaji dalam Tabel 4. Untuk bagian ini diolah 350 data dari subjek penelitian.
Tabel 4

Gambaran Toleransi Mahasiswa UIN Sunan Gunung Djati Bandung

\begin{tabular}{lcc}
\hline Kategori & Jumlah & Persentase \\
\hline Sangat Rendah & 13 & 3.71 \\
Rendah & 28 & 8 \\
Sedang & 277 & 79.14 \\
Tinggi & 21 & 6 \\
Sangat Tinggi & 11 & 3.14 \\
Total & 350 & 100 \\
\hline
\end{tabular}

Dari tabel 4 diketahui mahasiswa UIN Sunan Gunung Djati Bandung yang memiliki tingkat toleransi pada kategori sangat tinggi sebanyak 11 mahasiswa, lalu pada kategori tinggi sebanyak 21 mahasiswa. Tingkat toleransi mahasiswa lebih banyak berada pada kategori sedang yaitu sebanyak 277 mahasiswa. Kemudian pada kategori rendah sebanyak 28 mahasiswa dan pada kategori sangat rendah sebanyak 13 mahasiswa. Apabila memperhatikan gambar 1 dan 2, mayoritas subjek memiliki tingkat toleransi sedang. Ini bisa dimaklumi karena di lingkungan UIN subjek penelitian adalah subjek yang paham agama. Islam memerintahkan kepada umat untuk mengambil sikap moderat atau pertengahan untuk urusan dunianya. Ini tercantum dalam Alquran 
Surat Al Baqarah ayat 143 yang artinya: "Demikianlah kami menjadikan kalian sebagai umat yang bersikap pertengahan agar kalian bisa menjadi saksi atas manusia dan agar Rasul menjadi saksi atas kalian."

Tabel 5

Hasil Analisis Variansi pada Skor Toleransi

\begin{tabular}{lccccc}
\hline & $\begin{array}{c}\text { Sum of } \\
\text { squares }\end{array}$ & df & $\begin{array}{c}\text { Mean } \\
\text { square }\end{array}$ & F & Sig. \\
\hline $\begin{array}{l}\text { Between } \\
\text { Groups }\end{array}$ & 82.811 & 3 & 27.604 & .115 & .951 \\
$\begin{array}{l}\text { Within } \\
\text { Groups }\end{array}$ & 64603.510 & 270 & 239.272 & & \\
Total & 64686.321 & 273 & & & \\
\hline
\end{tabular}

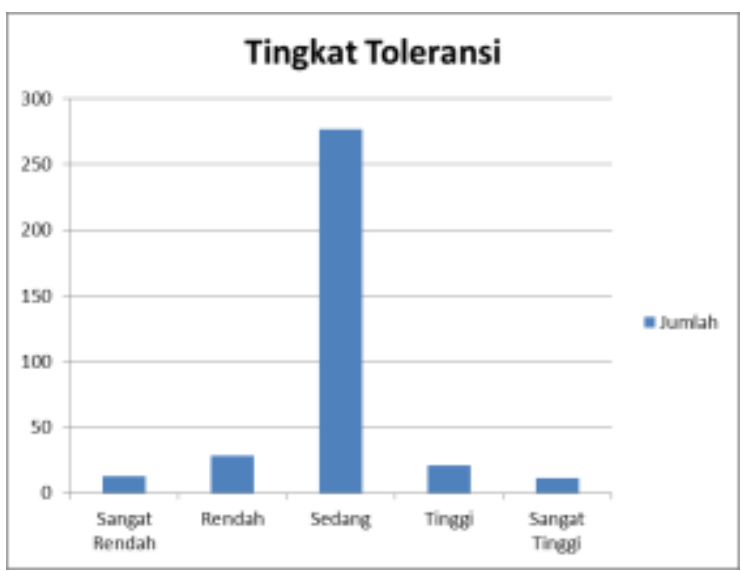

Gambar 1. Tingkat Toleransi Subjek

Selain itu, diduga ini juga bisa terjadi karena masyarakat kita tidak berani menempatkan dirinya sebagai individu yang berbeda dari kelompoknya. Sikap konformitas dalam suatu masyarakat yang komunal membuat sebagian individu untuk 'main aman' dalam mengekspresikan persepsinya. Dalam tulisannya tentang 'merayakan kebebasan beragama' Effendi (2009) menyebutkan bahwa saat ini banyak individu yang hidup dalam persepsi yang tidak sepenuhnya utuh terhadap keimanan dan kepercayaan golongan lain. Ketidakutuhan pemahaman ini menyebabkan penangkapan informasi yang sepotongsepotong sehingga dengan mudah menggeneralisasi sedikit saja 'perbedaan' menjadi sikap 'mengkafirkan' seluruh ajaran agama lain. Sikap bahwa 'agamaku yang paling benar' membuat kelompok ini menutup diri dari menerima kebenaran pada kelompok lain. Miskinnya pemahaman dan wawasan, kelompok ini juga tidak siap mendewasakan dirinya dengan proses dialog. Yang ditunjukkan adalah tindakan-tindakan anarkis yang di luar konteks intelektual.

Gambaran tipe kepribadian mahasiswa UIN Sunan Gunung Djati Bandung tersaji dalam gambar 2, gambar 3, dan gambar 4 . Untuk data tipe kepribadian, dari lima indikator yang ada, empat tipe muncul pada subjek. Data yang valid untuk diolah berjumlah 274 dari 350 subjek yang terbagi ke dalam tipe $\mathrm{E}(\mathrm{n}=10)$, tipe $\mathrm{C}(\mathrm{n}=147)$, tipe ES ( $n=70)$, dan tipe I $(n=47)$. Pada gambar 3 diperlihatkan histogramnya dan pada gambar 4 diperlihatkan diagram lingkaran untuk persentasenya. Tipe kepribadian Conscientiousness (C) mendominasi. Dapat dilihat juga rincian sifat-sifat yang muncul pada subjek penelitian menurut Big Five Personality seperti yang tercantum pada tabel 2.

Tipe kepribadian yang tidak muncul adalah Agreeableness yang memiliki indikator baik hati, suka bekerja sama, kooperatif, simpatik, ramah, dapat dipercaya, penuh pertimbangan, menyenangkan, bersedia menyetujui, suka menolong, murah hati. Pada kondisi negatif, kepribadian tipe ini ditandai dengan munculnya sifat-sifat sinis, kasar, rasa curiga, tidak mau bekerja sama, pendendam, kejam, mudah marah, dan manipulatif. Tapi belum dapat diketahui dengan pasti penyebab kondisi ini terjadi. Diperlukan penelitian yang lebih mendalam terhadap pola subjek memilih respon pada alat ukur. Keadaan ini bisa ditelusuri lebih jauh dengan mempelajari bias respon dalam memilih jawaban karena pada dasarnya seseorang ingin menampilkan diri dengan citra yang baik, bahkan memiliki tipe kepribadian ideal. Dalam konteks sikap toleransi mungkin subjek berhati-hati memilih respon agar tidak terkesan sebagai orang yang tidak toleran. 


\section{Statistika Inferensial}

Selanjutnya diberikan hasil Anova (Analysis of Variance) yang ditujukan untuk melihat perbedaan sikap intoleransi pada masing-masing tipe kepribadian dengan hipotesis $\mathrm{H}_{0}: \mu_{1}=\mu_{2}=\mu_{3}=\mu_{4}$ dan $\mathrm{H}_{1}$ : salah satu $\neq$, dimana $\mu$ adalah rata-rata skor pada masing-masing tipe kepribadian.

Perhatikan tabel 5. Dengan diperolehnya $p_{\text {value }}$ sebesar .951 maka untuk alpha sebesar .05 diperoleh $p_{\text {value }}>$ alpha. Ini artinya tidak terdapat perbedaan yang signifikan pada sikap toleransi keempat tipe kepribadian. Diduga ini karena nilai moral yang dimiliki oleh mayoritas mahasiswa UIN menempatkan mereka untuk menjadi individu yang toleran dalam menyikapi perbedaan.

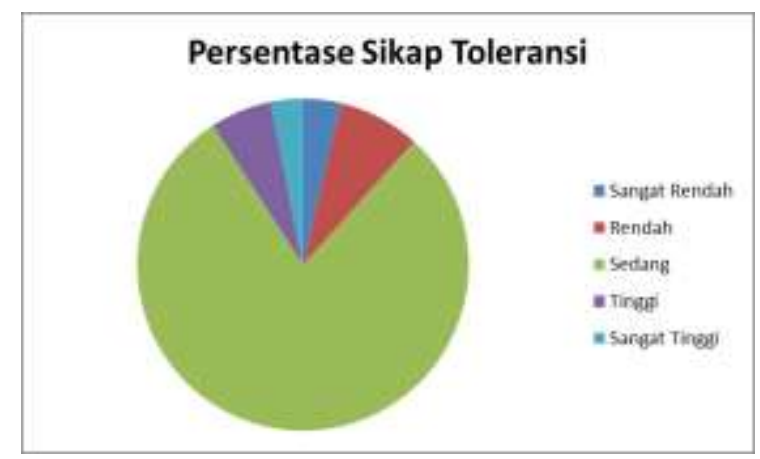

Gambar 2. Persentase Sikap Toleransi

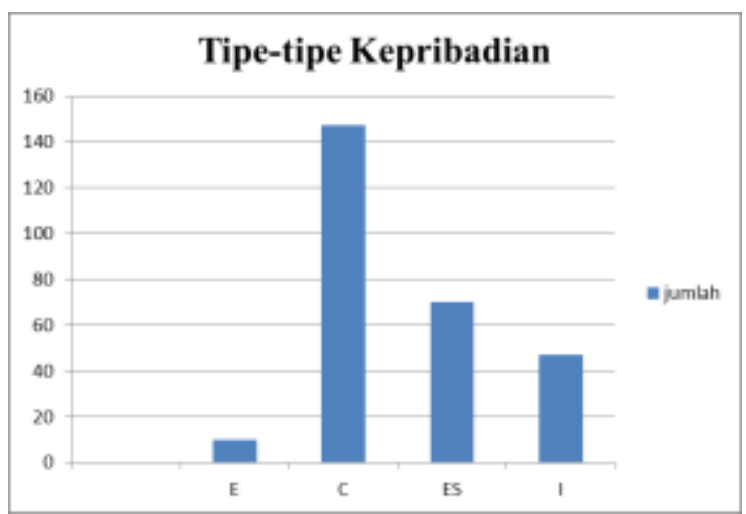

Gambar 3. Distribusi Frekuensi Berdasarkan Tipe Kepribadian

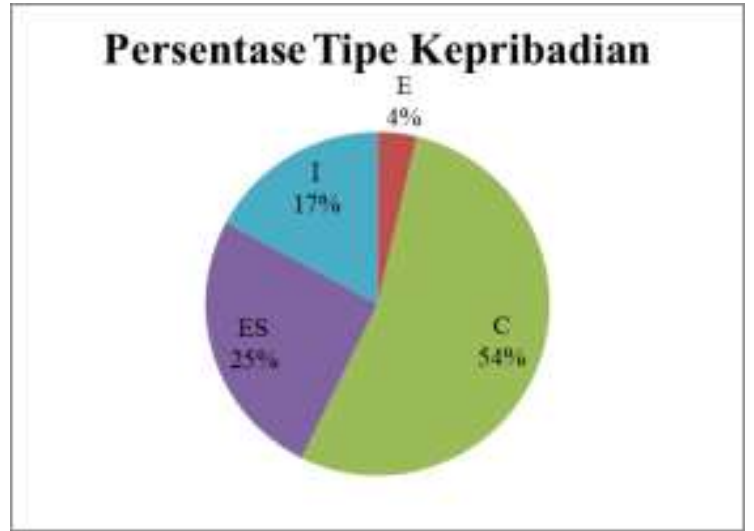

Gambar 4. Persentase Tipe Kepribadian Subjek

\section{Simpulan dan Saran}

Dari penelitian ini diketahui pentingnya pendidikan moral pada anak mulai usia sedini mungkin. Prinsip-prinsip seperti toleransi layaknya diperkenalkan sejak kecil melalui penanaman nilai dan teladan langsung dari orang tua. Jadi walaupun di sekolah sudah ada pengenalan sikap toleransi melalui pendidikan karakter yang diturunkan ke dalam mata pelajaran Agama serta Pendidikan Pancasila dan Kewarganegaraan (PPKn), tapi kedekatan anak dengan orang tua akan memberikan pendidikan yang lebih efektif.

Pentingnya proses dialog dan belajar lebih banyak lagi tentang prinsip-prinsip moral dalam agama, bisa disarankan untuk menjadi solusi bagi pertikaian yang tidak berkesudahan dari kelompok-kelompok yang tidak sepaham dan sealiran. Kajian tentang sejarah kenabian yang seharusnya bisa menjadi contoh bagaimana hidup berdampingan dengan pemeluk agama lain juga harus digalakan. Betapa Nabi Muhammad Saw. sangat mengedepankan unsur kedamaian dan tabayyun terhadap umat agama lain, sangat layak dan relevan untuk 'dihidupkan' kembali pada zaman sekarang.

Dari hasil-hasil penelitian yang sudah dijelaskan di atas dapat disimpulkan bahwa latar belakang agama mungkin bisa diteliti lebih lanjut untuk memastikan apakah pengetahuan agama yang memadai bisa menjadi faktor penentu dalam bersikap 
toleran walaupun individu memiliki tipe kepribadian yang berbeda-beda. Sekaligus mungkin bisa ditelusuri adakah keterkaitannya juga dengan nilai moral yang dimiliki.

Namun sebelum diteliti lebih jauh halhal di atas, bisa diawali terlebih dahulu dengan penelitian untuk mengetahui keberadaan bias respon pada tes kepribadian. Kesesuaian antara sikap dan perilaku dengan persepsi kepribadian yang ditampilkan juga perlu diteliti. Apalagi mengingat mahasiswa UIN mayoritas merupakan individu yang mempunyai pemahaman agama cukup baik. Hal ini perlu dilakukan mengingat bisa saja karena pengetahuan agama yang cukup baik, subjek mengetahui bagaimana seharusnya bersikap tetapi baru berada pada tataran persepsi, belum diaplikasikan melalui perilaku. Fenomena saat ini memperlihatkan banyak individu yang mengaku agamis tapi sempit dalam bertindak bahkan cenderung fanatik sehingga tingkat intoleransinya tinggi. Individu seperti ini bersama-sama akan mencari dan merekayasa 'musuh bersama', terutama yang tidak seagama atau tidak sepaham dalam urusan politik. Kedokkedok agama dikedepankan dengan alasan tidak boleh berhubungan baik dengan yang tidak sealiran agar tidak dianggap mengambil teman yang bukan dari kaumnya. Fenomena inilah yang saat ini menggejala pada masyarakat Indonesia. Walaupun jumlahnya tidak banyak namun militansi kelompok ini cukup mengganggu dan sering meresahkan masyarakat.

Selain itu, penelitian ini pada mulanya ingin melihat seberapa signifikan peran tipe kepribadian dalam diri seseorang yang memberikan potensi apakah individu tersebut mudah menjadi radikal atau tidak. Namun dalam hasil penelitian ini, tidak diperoleh hubungan yang signifikan antara tipe kepribadian dengan intensi radikal.

Ini didasari dari fenomena saat ini pesantren dituding sebagai salah satu institusi yang paling bertanggung jawab terhadap maraknya radikalisme. Padahal jika ditelaah lebih jauh, tidak ada kuriku- lum di pesantren yang mengajarkan untuk pemahaman radikal. Jika dapat diketahui ada pengaruh tipe kepribadian terhadap potensi radikal, maka akan bisa disarankan kepada pesantren-pesantren untuk terlebih dahulu melakukan psikotes pada calon santri. Para calon santri dengan tipe kepribadian yang terindikasi mudah menjadi radikal tidak perlu diterima.

\section{Daftar Pustaka}

Alford, K. L. (2009). Serving students: A conversation with Chad H. Webb. RE, 10(3).

al-Mubarakfuriyy, S. (2008). Seerah nabawiyyah, Al-raheeq al-makhtum. Samudra Ilmu. E-book.

Bahari. (2010). Toleransi beragama mahasiswa (studi tentang pengaruh kepribadian, keterlibatan organisasi, hasil belajar pendidikan agama, dan lingkungan pendidikan terhadap toleransi mahasiswa berbeda agama pada 7 Perguruan Tinggi Umum Negeri). Jakarta: Badan Litbang dan Diklat Kementerian Agama Puslitbang Kehidupan Keagamaan.

Bennett, M. J. (1993). Towards a developmental model of intercultural sensitivity. Dalam R.M. Paige (Ed.). Education for the intercultural experience education. Yarmouth, ME: Intercultural Press.

Broer, N. A., de Muynck, B., Potgieter, F. J., Wolhuter, C. C., \& van der Walt, J. L. (2014). Measuring religious tolerance among final year education students: The birth of a questionnaire. International Journal for Religious Freedom (IJRF), 7(1/2), 77-96.

Bukhori, B. (2012). Toleransi terhadap umat Kristiani ditinjau dari fundamentalisme agama dan kontrol diri. Semarang: Laporan Penelitian Individual.

Clark K. E., \& Ladd G. W. (2000). Connectedness and autonomy support in parent-child relationships: Links to 
children's socioemotional orientation and peer relationships. Developmental Psychology, 36(4), 485-498.

Dariyo, A. (2003). Psikologi perkembangan dewasa muda. Jakarta: PT Gramedia Widiasarana.

Dewi, A. P. (2017, 3 Juni). Polri: Intoleransi cikal bakal radikalisme. Antara News. Diakses 30 November, 2017 , dari https://www.antaranews.com/berita/63 2985/polri-intoleransi-cikal-bakalradikalisme

Dijiker, A., \& Koomen, W. (2007). Stigmatization, tolerance and repair. Cambridge, UK: Cambridge University Press.

Effendi, D. (2009). Merayakan kebebasan beragama: Bunga rampai menyambut 70 tahun Djohan Effendi. Jakarta: Penerbit Buku Kompas.

Gray, B. (2003). Framing of environmental disputes. Dalam R. Lewicki, B. Gray, \& M. Elliott (Eds.), Making sense of intractable environmental conflicts: Concepts and cases (pp. 11-34). Washington, D.C.: Island Press.

Hall, C. S., \& Lindzey, G. (2005). Psikologi kepribadian 1: Teori-teori psikodinamik (klinis). Yogyakarta: Kanisius.

Hermawati, R., Paskarina, C., \& Runiawati, N. (2016). Toleransi antar umat beragama di Kota Bandung. Umbara: Indonesian Journal of Anthropology, 1(2), 105-124.

Hurlock, E. B. (1968). Developmental psychology. New York: McGraw-Hill.

John, O. P. (1990). The "Big Five" factor taxonomy: Dimensions of personality in the natural language and questionnaires. Dalam L.A. Pervin (Ed.) Handbook of personality: Theory and research (pp. 66- 100). New York: Guilford Press.

Kant, I. (1785/1988). Fundamental principles of the metaphysics of morals. Buffalo, NY: Prometheus Books.
Kochanska, G., Gross, J. N., Lin, M. H., \& Nichols, K. E. (2002). Guilt in young children: Development, determinants, and relations with a broader system of standards. Child Development, 73, 461-482.

Kochanska, G., Koenig, J. L., Barry, R. A., Kim, S., \& Yoon, J. E. (2010). Children's conscience during toddler and preschool years, moral self, and a competent, adaptive developmental trajectory. Developmental Psychology, 46(5), 1320-1332. doi: 10.1037/a0020381.

Kohlberg, L. (1981). Essays on moral development, vol. $i$ : The philosophy of moral development. San Francisco, CA: Harper \& Row.

Komnas HAM. (2017, 16 Januari). Pada 2016, intoleransi meningkat. Komnas HAM. Diakses 30 November, 2017, dari

https://www.komnasham.go.id/index.p hp/news/2017/1/16/276/pada-2016intoleransi-meningkat.html

Kusumadewi, A. (2016, 10 Agustus). Yogyakarta, kota yang makin tak toleran. CNN Indonesia. Diakses 30 November, 2017, dari https://www.cnnindonesia.com/nasion al/20160808211440-20-

150068/yogyakarta-kota-yang-makintak-toleran

Moral. (2018). Di Kamus Besar Bahasa Indonesia. Diakses 30 November, 2017, dari http://kbbi.co.id/artikata/moral

Na'im, A., \& Syaputra, H. (2010). Kewarganegaraan, suku bangsa, agama, dan bahasa sehari-hari penduduk Indonesia. Jakarta: Badan Pusat Statistik.

Narvaez, D., Lapsley, D. K., Hagele, S., \& Lasky, B. (2006). Moral chronicity and social information processing: Tests of a social cognitive approach to the moral personality. Journal of Research in Personality, 40(2006), 966-985. 
Nucci, L. P., \& Narvaez, D. (2014). Handbook of moral and character education. Edisi terjemahan. Bandung: Penerbit Nusa Media.

Pervin, L. A., Cervone, D., \& John, O. P. (2004). Psikologi kepribadian: Teori dan penelitian. Edisi 9. Jakarta: Kencana Prenada Media Group.

Power, C., Higgins, A., \& Kohlberg, L. (1989). Lawrence Kohlberg's approach to moral education. New York: Columbia University Press.

Sari, D. A. (2010). Uji validitas alat ukur Big Five Personality (adaptasi dari IPIP) pada mahasiswa Universitas Islam Negeri Syarif Hidayatullah Jakarta (Skripsi). Fakultas Psikologi UIN Syarif Hidayatullah, Jakarta, Indonesia.

Sugiyono, A. S. (2015). Cara mudah belajar SPSS \& LISREL teori dan aplikasi untuk analisis data penelitian. Bandung: Alfabeta.
The Wahid Institute. (2013). Berkeyakinan dan intoleransi. Jakarta: The Wahid Institute.,km

The Wahid Institute. (2014). Laporan tahunan kebebasan beragama berkeyakinan dan intoleransi. Jakarta: The Wahid Institute.

Van der Walt, J. L. (2016). Religious tolerance and intolerance: 'Engravings' on the soul. In Die Skriflig. 50(1).

Westen, D., \& Shedle, J. (2007). Personality diagnosis with the ShedlerWesten Assessment Procedure (SWAP): Integrating clinical and statistical measurement and prediction. Journal of Abnormal Psychology, 116(4), 810-822.

Yulianto, A. (2017, 21 Maret). Darurat intoleran di Indonesia, itu tema diskusi milad IMM. Republika. Diakses 30 November, 2017, dari https://www.republika.co.id/amp_versi on/on5ihl396 